\title{
PERIODONTAL VACCINE: WILL THE DREAM EVER COME TRUE?
}

R. Hemalatha' ${ }^{1}$ R. Arun Kumar ${ }^{2}$

\section{HOW TO CITE THIS ARTICLE:}

R. Hemalatha, R. Arun Kumar. "Periodontal Vaccine: Will the Dream ever come true?". Journal of Evolution of Medical and Dental Sciences 2014; Vol. 3, Issue 55, October 23; Page: 12665-12671,

DOI: $10.14260 /$ jemds/2014/3677

\begin{abstract}
Vaccination is a process that induces specific immune resistance to a bacterial or viral infectious disease. Vaccines have prevented several infectious diseases for many years, and are still being investigated. Till date, no preventive modality exists for periodontal disease and treatment rendered is palliative. The current treatment of periodontitis is non-specific and is centered on removal of supra and sub gingival plaque debridement. Periodontal disease has been positively related to life-threatening systemic diseases such as atherosclerosis and diabetes. The objective of periodontal vaccine is to identify the antigens involved in the destructive process of periodontitis against which antibodies would be evoked to exert protection.
\end{abstract}

KEYWORDS: Vaccine, Periodontal vaccine, Immunization.

INTRODUCTION: Vaccination is induction of immunity by injecting a dead or attenuated form of a pathogen. ${ }^{1}$ Vaccination against bacterial/viral infectious diseases has progressed immensely throughout the 20th century. Periodontal diseases are one such group of infectious bacterial diseases, against which vaccine research is still going on. The complexities in the etiopathogenesis of the periodontal diseases have been the prime obstacle in the hunt for vaccine. Till date, no preventive modality exists for periodontal disease and treatment rendered is palliative.

Vaccination is the best-known and the most important application of immunological principles to human health. ${ }^{2}$ The first vaccine was named after vaccinia, the cowpox virus. Jenner pioneered its use 200 years ago. ${ }^{24}$ It was the first deliberate scientific attempt to prevent an infectious disease (small pox). Ever since the introduction of the smallpox vaccine by Edward Jenner in 1798, antigens of pathogenic bacteria and viruses have been the targets for a variety of vaccines against a number of infectious diseases.

\section{Characteristics of an effective Vaccine:}

- Safety.

- Protectivity.

- The ability to provide sustained protection.

- The ability to produce neutralizing antibodies.

- Stimulation of protective T-cells which provides cell mediated immunity.

\section{Significance of periodontal vaccine Development:}

- Chronic periodontitis is a poly microbial infection.

- Major cause of tooth loss worldwide.

- Periodontal disease contributes to the perpetuation of systemic R of critical importance (atherosclerosis, diabetes mellitus, etc.). ${ }^{28}$ 
Periodontal disease and systemic Illness-relationship: An elevated systemic level of inflammatory mediators like C-reactive protein and fibrinogen ${ }^{27}$ in severe periodontal disease which may predispose to various conditions like myocardial infarction, cerebrovascular stroke, preterm low birth weight infants in susceptible individuals. ${ }^{28}$

\section{Indications for periodontal vaccine: ${ }^{3}$}

- Severe periodontal disease with loss of bone around teeth.

- Inflammation and association with oral bacterial infection below gum line.

- Exacerbated diabetes and CVD.

Periodontal Pathogens: P. gingivalis, Tanerella forsythia, Treponema denticola (the RED COMPLEX) and Aggregatibacter actinomycetem comitans have been consistently and strongly associated with progression of disease, suggesting that these four bacterial species may be the major pathogens of periodontitis in humans. ${ }^{4}$

Types of Vaccination: Active Immunization: Here an individual immune system is stimulated by administrating killed or live attenuated products derived from micro-organisms.

Passive Immunization: Here, the antibodies formed in one individual are transferred to another.

DNA Vaccination: Here, DNA plasmids encoding genes required for antibodies production are transferred to an individual.

Active Immunization: Primary antigenic model for vaccine development- P. gingivalis.

Whole Cells: The entire cell with its components is inoculated into a host to bring about active immunization.

Klausen 19916 have shown that levels of serum antibodies to both whole cells and partially purified fimbriae from P.gingival are were elevated in rats immunized with P. gingivalis cells.

Kesavalu $1992^{7}$ observed protection against invasion, but no colonization against P. gingivalis in a mouse chamber model by immunization with either killed heterologous invasive or non-invasive P. gingivalis strains.

P. gingivalis, a gram-negative, non-spore/forming, non-motile, assacharolytic, obligate anaerobic coccobacillus has emerged as the leading candidate pathogen in the development of chronic periodontitis. ${ }^{8}$

The virulence factors of $\mathrm{P}$. gingivalis which have been used as subunits for the development of active immunization are: ${ }^{9}$

a) Outer membrane protein.

b) Gingipains.

c) Fimbriae and.

d) Heat shock protein. 
Outer membrane Protein: It was seen that transcutaneous injection of $40 \mathrm{kDa}$ of outer membrane protein (OMP) inhibits co aggregation of P. gingivalis with Streptococcus gordonii. This also can be used for vaccine development for passive immunization. Polyclonal anti40 kDa OMP antibody exhibited potentially protective, complement mediated bactericidal effect. 10

Gingipains: These are cysteine proteinases which cleave synthetic and natural substrates after arginine or lysine residues and are referred to as arginine gingipain (Rgp) and lysine gingipain (Kgp), respectively. ${ }^{11-14}$

Rgp and Kgp are key determinants in the growth and virulence of P. gingivalis. ${ }^{15}$

Gibson et al., showed that immunization with Rgp A stimulates the production of hemagglutinin domain specific antibodies which contribute to the prevention of $\mathrm{P}$. gingivalis mediated oral bone loss. ${ }^{11}$

Therefore, it is likely that virulence of P. gingivalis can be attenuated by inactivation of Rgp and Kgp with proteinase inhibitors of antibodies specific to Rgp and Kgp. Therefore, Rgp and Kgp may be useful as vaccine against periodontal diseases.

Gingipain vaccines are mainly DNA vaccines. ${ }^{11}$ DNA vaccines induce both humoral and cellular immunity. ${ }^{11}$

Fimbriae: Fimbriae from P. gingivalis are cell surface structure component that plays an important role in adhesion to oral tissue and are highly immunogenic. ${ }^{26}$

\section{Functions of fimbriae are the following:}

(a) Adherence to host.

(b) Invasion of oral epithelial cells and fibroblasts.

(c) Modulation of inflammation by release of interleukin (IL), tumor necrosis factor (TNF). ${ }^{16}$

Currently, five $\mathrm{P}$. gingivalis fimbrial types (I-V) have been described based on their antigenicity. However, a vaccine based on one fimbrial type may be strain specific and hence ineffective against other P. gingivalis strains of different fimbrial types.

GroEL heat shock Protein: Heat shock proteins have an important role in inflammatory mechanism, autoimmune disease and atherosclerosis. Significant association between HSP90 concentration and microbial colonization has been observed. ${ }^{25}$

Hemagglutinins: Hemagglutinin mediates bacterial attachment and penetration into the host cells, as well as agglutinates and lyses erythrocytes to intake heme, an absolute requirement for growth. Non-fimbrial adhesion hemagglutinin B (HagB) is a potential vaccine candidate. Development of this monoclonal antibody may be useful for passive immunization as well as assessment of treatment for periodontal disease caused by P. gingivalis infection. ${ }^{18}$

Passive immunization: Passive immunization is short lived because host does not respond to immunization and protection lasts only as long as injected antibody persists. Antigens are injected into vectors that produce antibodies. These antibodies when inoculated into host bring about passive immunization. ${ }^{3}$ 


\section{REVIEW ARTICLE}

\section{Passive immunization can be brought about in two Ways:}

1. Murine monoclonal antibodies.

2. Plantibodies.

Murine monoclonal Antibodies: In this, the antibodies are obtained by inoculating the antigens into mice. These antigens are then injected into the host that brings about passive immunization. ${ }^{19}$

Booth; 1996 developed a murine monoclonal antibody to P. gingivalis that prevented re colonization of deep pockets by this pathogen in periodontitis patients.

Plantibodies: A very recent approach for vaccination strategies is molecular biological techniques to express bacterial or viral antigens in plants, which could be used as orally administered vaccines. ${ }^{20}$

Ma; 2000, characterized a secretory IgG antibody against Streptococcus mutans produced in transgenic plants.

\section{Advantages:}

a. Higher stability.

b. Higher degree of functionality.

Genetic Immunization: Gene therapy is insertion of genes into an individual cells and tissues to treat a disease. The strategy involves genetic engineering or recombinant DNA technology. ${ }^{21}$

\section{There are two Types:}

- Plasmid vaccines.

- Live, viral vector vaccines.

Plasmid Vaccines: DNA does not have ability to grow whereas plasmids have ability to grow. With this ability of the plasmids, they are fused with DNA of a particular pathogen of interest and inoculated in an animal for production of antibodies. This is then transferred to the host for immunization.

Disadvantages: In some cases it may lead to oncogenesis.

Live, viral vector vaccines: Variety of infectious but non-disease causing DNA or RNA viruses or bacteria has been engineered to express the proteins of a disease producing organism. The vector enters the body cells where the proteins are generated and then induce humoral or cellular immune responses. ${ }^{3}$

\section{Methods of DNA Vaccine Administration:}

1. Intranasal.

2. Intramuscular.

3. Gene gun. 


\section{Advantages of DNA Vaccines:}

1. Ease of manipulation.

2. Stable by nature.

3. Simple.

Setbacks of periodontal Vaccine: Though periodontal vaccine is successful on animal models, it is still a dream on humans as it has many limitations:

- Complexity and uncertainty of the different forms of periodontal diseases. So determination of an antigen for the vaccine may pose as a major limitation.

- To accurately differentiate between primary colonizers and secondary invaders.

- The relative difficulty in growing and identifying many of the disease-associated microorganisms and the variability of the plaque composition from one individual to the other and between sites in the same individual.

- Difficulty in clinically detecting and quantitating active periodontal disease.

- The nonfatal nature of the disease.22

Moreover, animals differ qualitatively from humans, with respect to the oral microbial ecosystem, the histological components of the periodontal lesions, the nature of immune responses and control over immunoglobin class and subclass responses. So, results of animal studies may not be directly generalized to humans. Most of the tested approaches afforded short-term protection thus challenge exists in maintaining immune memory to prevent reinfection at a later date and also to trigger T-cell dependent immune responses. Toxic reactions against vaccines based on killed bacteria may occur.

\section{Bacterial species Antigens Biologic Effects:}

A. actinomycetemcomitans Leukotoxin Inhibition of PMN function.

T. forsythia Heat-sensitive surface protein arresting of lymphocyte cell cycle.

T. denticola Inhibition of superoxide production Decreased bacterial killing.

The above said antigenic targets of respective bacterial species involved in triggering immune response are potential candidates in the production of vaccine. ${ }^{29}$

CONCLUSION: Vaccination may be an important adjunctive therapy to mechanical debridement in near future. As periodontitis significantly increases the risk for potentially fatal diseases such as coronary heart disease, stroke and complications from diabetes mellitus, a successful vaccine for periodontitis could have health benefits far exceeding the prevention of periodontitis. This poly microbial infection needs further research and clinical trials using combined proteomic genomic immunologic strategy to generate multispecies periodontal vaccine.

\section{REFERENCES:}

1. Roderich N. Immunology. In: Brooks GF, Butel JS, Morse SA, editors. Javetz, Melnik and Adelberg's Medical Microbiology. 23rd ed. 2004. p. 121

2. Roitt, Brostoff, Male. Text book of Immunology. $4^{\text {th }}$ ed. 1998. 
3. Kudyar N, Dani N and Mahale S. Periodontal Vaccine: A dream or reality, Journal of Indian Society of Periodontology 2011; 15 (2): 115-120.

4. Ishikawa I, Nakashima K, Koseki T, Nagasawa T, Watanabe H, Arakawa S, et al. Induction of immune response to periodontopathic bacteria and its role in pathogenesis of periodontitis. Periodontology 2000 1997; 14: 79-111.

5. Reid R and Roberts F. Textbook of pathology illustrated 6th ed. Churchill Livingstone; 2005.

6. Klausen B, Evans RT, Ramamurhty NS, Golub LM, Sfintescu C, Lee IY, et al. Periodontal bone level and gingival proteinase activity in gnotobiotic rats immunized with Bacteroides gingiva/are. Oral Microbiol Immunol 1991; 6: 193-201.

7. Kesavalu L, Ebersole JL, Machen RL, Holt SC. Porphyromonas gingivalis virulence in mice: Induction of immunity to bacterial components. Infect Immun 1992; 60: 1455-64.

8. Micael CL and Peter LM. Oral microbiology and the immune response. In: Richard IJ. Robert BA, Martilyn LS, Donald J and Le Blanc, editors, Oral Microbiology and Immunology. 1sted.2006.Pg.201-2.

9. Nail BS, Paul VD and Staurt DG.Antigens of bacteria associated with periodontitis. Periodontology 2000 2004; 35: 101-34.

10. Katoh M, Saito S, Takiguchi H, Abiko Y. Bactericidal activity of a monoclonal antibody against a recombinant 40kDa outer membrane protein of Porphyromonas gingivalis. J Periodontol 2000; 71:368-75.

11. Marawar PP, Devkar N. Gingipains: The virulence factor of P. Gingivalis. J Indian Soc Periodontol 2004; 7: 95-9.

12. Monica F, Lilia MC, Roberta MJ. Humoral immune response to antigen of porphyromonas gingivalis ATCC33277 in chronic periodontitis. J Appl Oral Sci 2007; 15: 213-9.

13. Moritz AJ, Capelli D, Lantz MS, Holt SC, Ebersole JL. Immunization with Porphyromonas gingivalis cysteine protease effects on experimental gingivitis and ligature induced periodontitis in Macaca fascicularis.J Periodontol 1998; 69: 686-97.

14. Yokoyama K, Sugano N, Shimada T, Shofiqur RA, Ibrahim el-SM, Isoda R, et al. Effects of egg yolk antibody against $\mathrm{P}$. gingivalis gingipains in periodontitis patients. J Oral Sci 2007; 49: 201-6.

15. Nakagawa T, Saito1 A, Hosaka $Y$ and Ishihara K. Gingipains as candidate antigens for Porphyromonas gingivalis vaccine. Keio J Med 2003; 52 (3): 158-162.

16. Person RG. Immune responses and vaccination against periodontal infection. J Clin Periodontol 2005; 32: 39-53.

17. Lopatin DE, Shelburne CE, Van Poperin N, Kowalski CJ, Bagramian RA. Humoral immunity to stress proteins and periodontal disease. J Periodontol 1999; 70: 1185-93

18. Kaizuka K, Hosogi Y, Hayakawa M, Shibata Y, Abiko Y. Human monoclonal antibody inhibits Porphyromonas gingivalis hemagglutinin activity. J Periodontol 2003; 74: 38-43.

19. Gupta RK, Varanelli CL, Griffin P, Wallach DF, Siber GR. Adjuvant Properties of NonPhospholipid Liposomes (Novasomes $囚$ ) in Experimental Animals for Human Vaccine Antigens. Vaccine. 1996; 14: 219-25. [PubMed: 8920703].

20. European journal of plant pathology. 1992; 98

21. Malhotra R, Kapoor A, Grover V and Tuli K A. Periodontal Vaccine, Indian Journal of Dental Research 2011; 22 (5): 698-705. 
22. William MP, William CB. Specific antibodies and their potential role in periodontal diseases. J Periodontol 1993; 64 (8 Suppl): 807 18-23.

23. Vaccination against periodontitis: the saga continues.Sharma DC, Prasad SB, Karthikeyan BV. Expert Rev Vaccines. 2007; 6 (4): 579-90.

24. Sharma N and Khuller N. Periodontal Vaccine: A New Paradigm for Prevention of Periodontal Diseases, J Oral Health Comm Dent 2010; 4 (Spl): 23-28.

25. Lopatin DE, Shelburne CE, Van Poperin N, Kowalski CJ, Bagramian RA. Humoral immunity to stress proteins and periodontal disease. J Period

26. Cullen PA, Haake DA, Adler B. Outer membrane proteins of pathogenic spirochetes, FEMS Microbiol Rev 2004; 28: 291-318.

27. Kweilder M, Lowe GD, Murray GD, Kinane DF, McGowan DA. Dental disease, fibrinogen and white cell count: Links with myocardial infarction. Scott Med J 1993; 38: 73-4.

28. Raul GI, Michelle HM, Elizabeth KA. Relationship between periodontal disease and systemic health. Periodontology 2000 2001; 25: 21-36.

29. Michael CL, Peter LM. Oral microbiology and the immune response. In: Richard LJ, Robert BA, Martilyn LS, Donald J. LeBlanc, editors. Oral Microbiology and Immunology. 1st ed. 2006. p. 201-2.

\section{AUTHORS:}

1. R. Hemalatha

2. R. Arun Kumar

\section{PARTICULARS OF CONTRIBUTORS:}

1. Reader, Department of Periodontics, Karpaga Vinayaga Institute of Dental Sciences, Kancheepuram District.

2. Associate Professor, Department of Pharmacology, Chettinad Hospital and Research Institute, Kelambakkam, Kancheepuram District.

\section{NAME ADDRESS EMAIL ID OF THE} CORRESPONDING AUTHOR:

Dr. R. Hemalatha,

Reader,

Department of Periodontics,

Karpaga Vinayaga Institute of

Dental Sciences,

Kancheepuram District.

Email: drhemamds@yahoo.co.in

Date of Submission: 28/08/2014.

Date of Peer Review: 29/08/2014.

Date of Acceptance: 16/10/2014.

Date of Publishing: 23/10/2014. 